\title{
Traffic-related air pollution associated with prevalence of asthma and COPD/chronic bronchitis. A cross-sectional study in Southern Sweden
}

\author{
Anna Lindgren*1, Emilie Stroh ${ }^{1}$, Peter Montnémery², Ulf Nihlén ${ }^{3,4}$, \\ Kristina Jakobsson ${ }^{1}$ and Anna Axmon ${ }^{1}$
}

\begin{abstract}
Address: ${ }^{1}$ Department of Occupational and Environmental Medicine, Lund University, Lund, Sweden, ${ }^{2}$ Department of Community Medicine, Lund University, Lund, Sweden, ${ }^{3}$ Astra Zeneca R\&D, Lund, Sweden and ${ }^{4}$ Department of Respiratory Medicine and Allergology, Lund University, Lund, Sweden

Email: Anna Lindgren* - anna.lindgren@med.lu.se; Emilie Stroh - emilie.stroh@med.lu.se; Peter Montnémery - peter.montnemery@med.lu.se; Ulf Nihlén - Ulf.Nihlen@med.lu.se; Kristina Jakobsson - kristina.jakobsson@med.lu.se; Anna Axmon - anna.axmon@med.lu.se

* Corresponding author
\end{abstract}

Published: 20 January 2009

International Journal of Health Geographics 2009, 8:2 doi:10.1186/1476-072X-8-2

This article is available from: http://www.ij-healthgeographics.com/content/8/I/2

(c) 2009 Lindgren et al; licensee BioMed Central Ltd.

This is an Open Access article distributed under the terms of the Creative Commons Attribution License (http://creativecommons.org/licenses/by/2.0), which permits unrestricted use, distribution, and reproduction in any medium, provided the original work is properly cited.
Received: 2 October 2008

Accepted: 20 January 2009

\begin{abstract}
Background: There is growing evidence that air pollution from traffic has adverse long-term effects on chronic respiratory disease in children, but there are few studies and more inconclusive results in adults. We examined associations between residential traffic and asthma and COPD in adults in southern Sweden. A postal questionnaire in $2000(n=9319,18-77$ years $)$ provided disease status, and self-reported exposure to traffic. A Geographical Information System (GIS) was used to link geocoded residential addresses to a Swedish road database and an emission database for NOx.

Results: Living within $100 \mathrm{~m}$ of a road with $>10$ cars/minute (compared with having no heavy road within this distance) was associated with prevalence of asthma diagnosis $(O R=1.40,95 \% \mathrm{Cl}=$ I.04-I.89), and COPD diagnosis $(\mathrm{OR}=1.64,95 \% \mathrm{Cl}=\mathrm{I} . \mathrm{II}-2.4)$, as well as asthma and chronic bronchitis symptoms. Self-reported traffic exposure was associated with asthma diagnosis and COPD diagnosis, and with asthma symptoms. Annual average NOx was associated with COPD diagnosis and symptoms of asthma and chronic bronchitis.

Conclusion: Living close to traffic was associated with prevalence of asthma diagnosis, COPD diagnosis, and symptoms of asthma and bronchitis. This indicates that traffic-related air pollution has both long-term and short-term effects on chronic respiratory disease in adults, even in a region with overall low levels of air pollution.
\end{abstract}

\section{Background}

Traffic-related air pollution is well known to have shortterm effects on chronic respiratory disease, exacerbating symptoms and increasing hospital admissions for respiratory causes [1]. Strong effects on symptoms have also been observed in areas with relatively low background pollu- tion [2]. Long-term effects have been disputed, but there is growing evidence that traffic-related air pollution is related, at least among children, to asthma incidence [3$7]$, decreased lung function development $[8,9]$, and incidence of bronchitic symptoms $[4,10]$. 
In adults, studies of long-term effects from traffic-related air pollution have been few, and recent studies have found both positive [11-15] and negative [16-18] associations with asthma, as well as positive $[16,19,20]$ and negative $[13,14]$ associations with COPD. Overall, chronic respiratory disease in adults is heterogenous and involves major exposures, such as personal smoking and occupational exposure, which do not directly affect children. This larger variety of risk factors may complicate research and contribute to inconclusive results in adults.

Self-reported living close to traffic has been associated with prevalence of asthma, but not COPD, among adults in southern Sweden [14]. However, self-reports could be severely biased if people are more aware of (and hence over-report) exposures that are known to be potentially connected to disease, and may not be trustworthy if used as the only exposure estimate [21].

One way of obtaining objective exposure estimates is the use of Geographical Information Systems (GIS) to combine geocoded population data with external traffic exposure data, such as road networks and modeled or monitored traffic pollutants. Since the concentrations of many traffic pollutants decline to background levels within 30-200 m of a road, the level of spatial aggregation may be just as important as the type of proxy when estimating exposure $[22,23]$. Some studies have found that adverse effects on respiratory disease are best captured with simple variables of traffic density and proximity to roads [24], rather than more complex models of specific pollutants, which are difficult to model with a high resolution. However, air pollutant models do have a number of advantages; for example, they can account for total traffic density, and can also be validated against real measurements, providing more specific estimates of the level of pollution at which adverse effects from traffic can be seen.

In the present study, we made use of a high quality GISmodeled pollutant database for nitrogen oxides $\left(\mathrm{NO}_{\mathrm{x}}\right.$ and $\mathrm{NO}_{2}$ ) which has been developed and validated for southern Sweden [25]. The high spatial variability of $\mathrm{NO}_{\mathrm{x}}$ $\left(\mathrm{NO}+\mathrm{NO}_{2}\right)$, with traffic as the dominating source, makes it a better proxy for exposure to traffic at the local level, compared with pollutants such as $\mathrm{PM}_{2.5}$ which have a more geographically homogenous spread [26]. We also used GIS-based road data and self-reported living close to heavy traffic as proxies for exposure.

\section{Study aim}

The aim of this study was to investigate the association between traffic-related air pollution and asthma and COPD in adults. The outcomes investigated were prevalence of; 1) asthma diagnosis 2) COPD diagnosis 3) asthma symptoms last 12 months, and 4) chronic bronchitis symptoms, in relation to residential traffic exposure.

\section{Methods}

Study area

The study area was the most southwestern part of Sweden (figure 1), the most populated part of the county of Scania. The study area contains 840000 of Sweden's total population of 8.9 million, and has a population density of 170 inhabitants per $\mathrm{km}^{2}$ (data from 2000). The majority of the population live in six of the communities, the largest of which is Malmö, the third largest city in Sweden, with a population of 260000 . A detailed regional description has previously been given [27]. In the geographical stratification of the present study, "Malmö" refers strictly to the city boundaries of Malmö, not the larger municipality.

The climate in the region is homogenous. Although pollutant levels in the region are low in an European context, they are higher than in the remainder of Sweden [28], due to long-range transport of pollutants from the continent and extensive harbor and ferry traffic.

\section{Study population \& questionnaire}

In 2000, a questionnaire was sent to a total of 11933 individuals aged 18-77, of whom 9319 (78\%) answered. The study population originated from two different study populations, with 5039 (response rate: 71\%) from a new random selection, and 4280 (response rate: $87 \%$ ) constituting a follow-up group from an earlier selection [29].

The questionnaire dealt with respiratory symptoms, potential confounders such as smoking habits and occupation, and exposures such as living close to a road with heavy traffic [29]. An external exposure assessment was also obtained by geocoding the residential addresses (as of 2000) of both respondents and non-respondents. This was achieved by linking each individual's unique 10-digit personal identity codes to a registry containing the geographical coordinates of all residential addresses.

Non-respondents had a higher mean of $\mathrm{NO}_{\mathrm{x}}$ than respondents; $14.7 \mu \mathrm{g} / \mathrm{m}^{3}$ versus $13.5 \mu \mathrm{g} / \mathrm{m}^{3}$. To a large extent this was due to a lower response rate in the more polluted city of Malmö (73\% vs. $80 \%$ in the remaining region).

\section{Outcome measures}

The following outcomes were investigated, as obtained by the postal questionnaires:

- Diagnosis of asthma. "Have you been diagnosed by a doctor as having asthma?" 


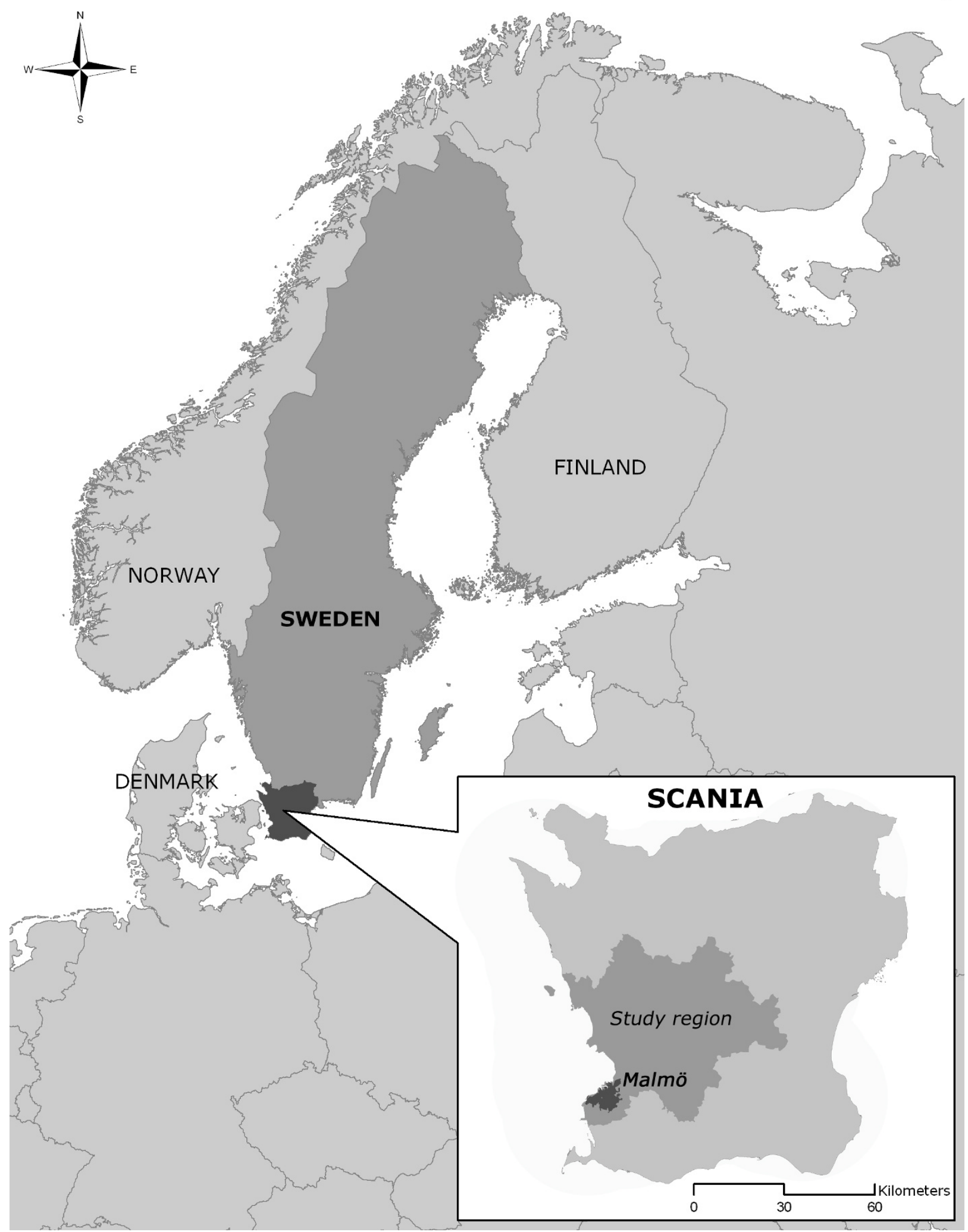

Figure I

Study area. Malmö is the largest city in the study region, which comprises the southwestern part of Sweden. 
- Diagnosis of COPD/CBE (Chronic Bronchitis Emphysema). "Have you been diagnosed by a doctor as having chronic bronchitis, emphysema, or COPD?"

- Asthma symptoms during the last 12 months. "Have you had asthma symptoms during the last 12 months, i.e. intermittent breathlessness or attacks of breathlessness? The symptoms may exist with or without cough or wheezing."

- Chronic bronchitis symptoms. "Have you had periods of at least three months where you brought up phlegm when coughing on most days?", and if so, "Have you had such periods during at least two successive years?"

The questionnaire has been published previously [29]. No information regarding year of disease onset was available.

\section{Exposure assessment}

Exposure to traffic-related air pollution was assessed at each participant's residential address in 2000, using three different proxies:

1. Self-reported exposure to traffic. This was obtained from the survey. Exposure was defined as a positive answer to the question "Do you live close to a road with heavy traffic?"

2. Traffic intensity on the heaviest road within $100 \mathrm{~m}$. GIS-based registers from The Swedish National Road Database [30] provided information about traffic intensity for all major roads in the county (figure 2). To assess exposure to traffic, we identified the road with the heaviest traffic intensity within $100 \mathrm{~m}$ of the residence. Traffic intensity was categorized as $0-1 \mathrm{cars} / \mathrm{min}, 2-5 \mathrm{cars} / \mathrm{min}$, 6-10 cars/min, and >10 cars/min, based upon 24 -hour mean levels.

3. Modeled exposure to $\mathrm{NO}_{\mathrm{x}}$ (figure 3). Annual mean concentrations of $\mathrm{NO}_{\mathrm{x}}$ were acquired from a pollutant database, based on the year 2001 [25,31]. Emission sources included in the model were: road traffic, shipping, aviation, railroad, industries and larger energy and heat producers, small scale heating, working machines, working vehicles, and working tools. Meteorological data were also included. A modified Gaussian dispersion model (AERMOD) was used for dispersion calculations; a flat twodimensional model which did not adjust for effects of street canyons or other terrain, but which did take the height of the emission sources into consideration. Concentrations of $\mathrm{NO}_{\mathrm{x}}$ were modeled as annual means on a grid with a spatial resolution of $250 \times 250 \mathrm{~m}$. Bilinear interpolation was used to adjust individual exposure with weighted values of neighboring area concentrations. Concentrations modeled with this spatial resolution have been validated and found to have a high correlation with measured values in the region $[25,31]$.

\section{Statistics}

A categorical classification of $\mathrm{NO}_{\mathrm{x}}$ was used in order to allow analysis of non-linear associations with outcomes. To determine the category limits, the subjects $(n=9274)$ were divided into $\mathrm{NO}_{\mathrm{x}}$-quintiles. The five exposure groups used were $0-8 \mu \mathrm{g} / \mathrm{m}^{3}, 8-11 \mu \mathrm{g} / \mathrm{m}^{3}, 11-14 \mu \mathrm{g} / \mathrm{m}^{3}, 14-19$ $\mu \mathrm{g} / \mathrm{m}^{3}$, and $>19 \mu \mathrm{g} / \mathrm{m}^{3}$.

For all measures of exposure, subgroup analyses were made for Malmö and the remaining region. Relative risk was not estimated in exposure groups with fewer than 50 individuals. As few individuals in Malmö had a low exposure to $\mathrm{NO}_{\mathrm{x}^{\prime}}$ the middle exposure group was used as the reference category for $\mathrm{NO}_{\mathrm{x}^{\prime}}$ in Malmö. Because of this, $\mathrm{NO}_{\mathrm{x}}$ was also used as a continuous variable for trend analysis using logistic regression. A p-value $<0.05$ was regarded as evidence of a trend. Stratified analyses were performed for sex, age, smoking, geographical region (Malmö vs. remaining region), and study population (new random selection vs. follow-up group). Sensitivity analyses of the associations with traffic were also performed by restricting the groups to those with asthma but not COPD, and COPD but not asthma, to exclude confounding by comorbidity. This process was also followed for symptoms.

Relative risk was estimated using Odds Ratios (ORs) with 95\% Confidence Intervals (CI). Odds Ratios and tests of trends were obtained by binary logistic regression, using version 13.0 of SPSS.

Sex, age (seven categories), and smoking (smokers/exsmokers vs. non-smokers) are known risk factors for asthma, and were therefore adjusted for in the model. Socio-Economic Indices (SEI codes, based on occupational status [32]) and occupational exposure (ALOHA JEM [33]) were tested as confounders, using the "changein-estimate" method [34], where a change in the OR of $10 \%$ would have motivated an inclusion in the model.

Neither occupational exposure nor Socio-Economic Indices fulfilled the predetermined confounder criteria, or had any noticeable impact on the risk estimates, and were thus not included in the model.

\section{Results}

A description of the study population in terms sex, age, and smoking, along with the associations with the outcomes, is presented in table 1.

\section{Association with self-reported living close to traffic}

Asthma diagnosis and asthma symptoms in the last 12 months were associated with self-reported traffic exposure 


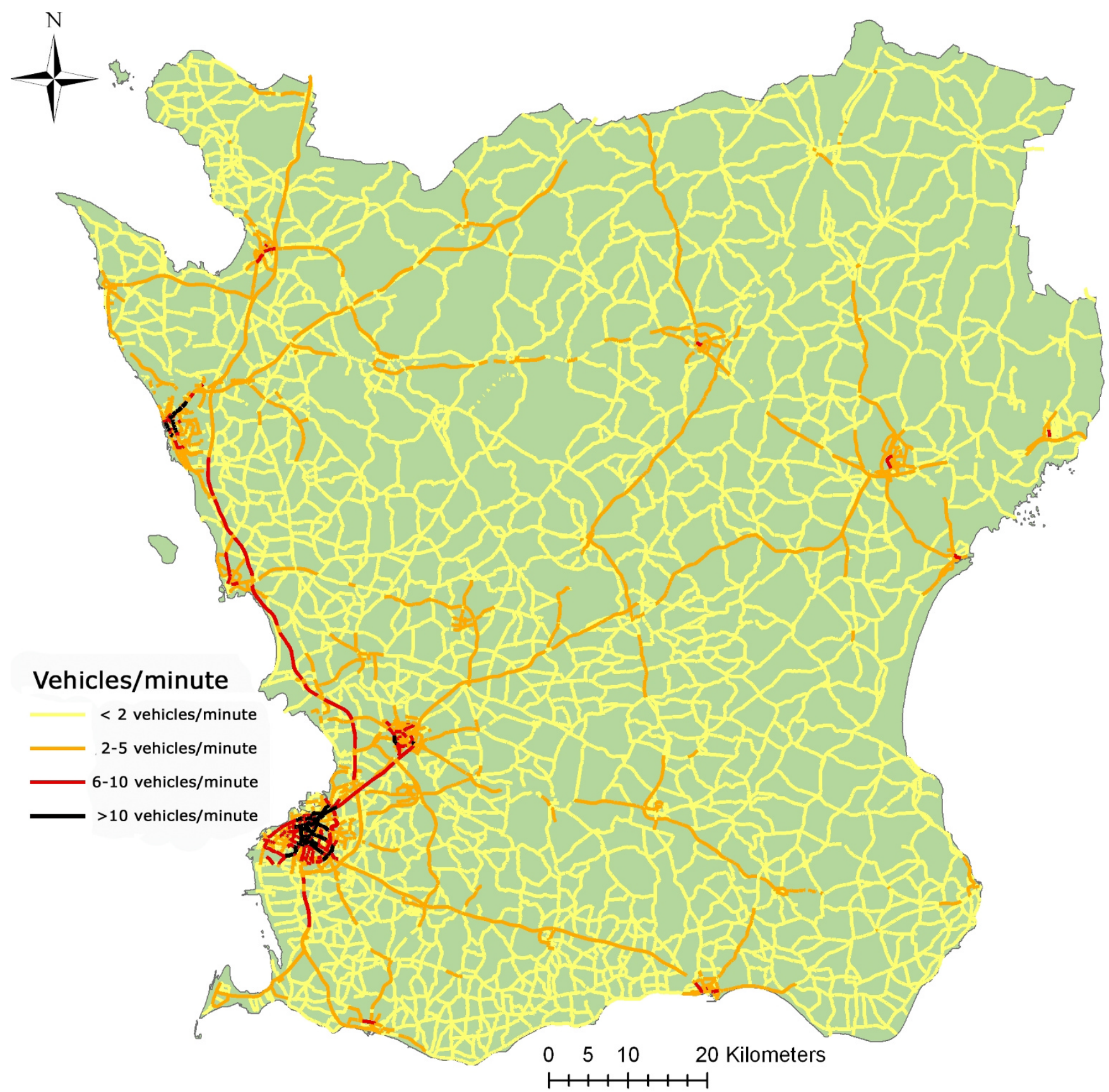

\section{Figure 2}

Regional road network. Data from the Swedish National Road Network. No heavy road means that no registered road was available in the database, but local traffic could exist. The traffic intensity categories of $(0-1,2-5,6-10,>10)$ cars/min corresponds to daily mean traffic counts of $(0-2880,2880-8640,8640-14400,>14400)$ cars/day.

(table 2). These results were consistent in a geographical stratification (tables 3, 4).

COPD diagnosis was associated with self-reported traffic exposure, both for the whole region (table 5) and when geographically stratified (table 6). Chronic bronchitis symptoms were not associated with self-reported traffic exposure (tables 5,7 ).

\section{Association with traffic intensity on heaviest road within $100 \mathrm{~m}$}

Asthma diagnosis and asthma symptoms were associated with traffic intensity (table 2), with higher prevalence of 


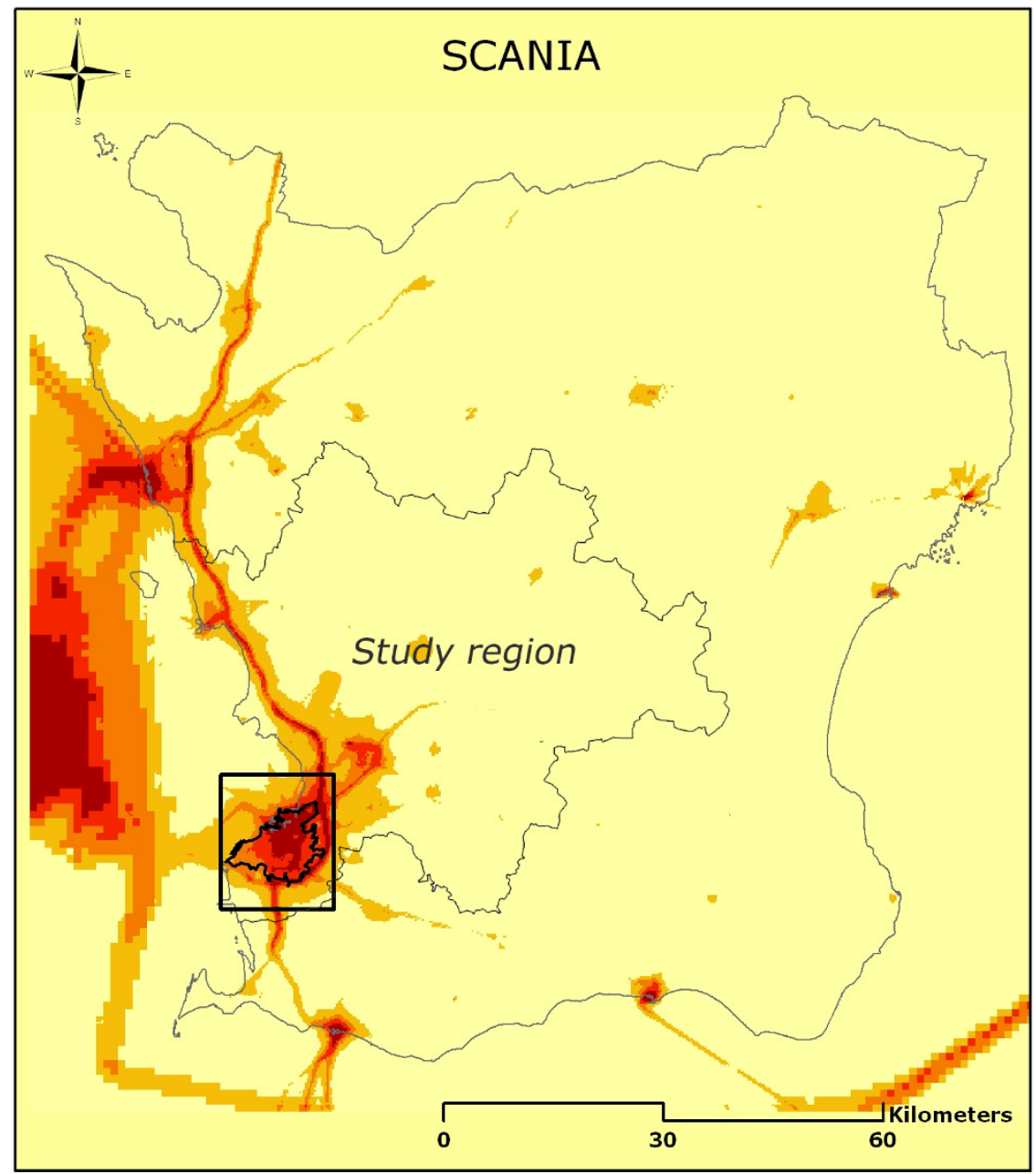

$\mathrm{NO}_{x}$ concentrations $\left(\mu \mathrm{g} / \mathrm{m}^{3}\right)$

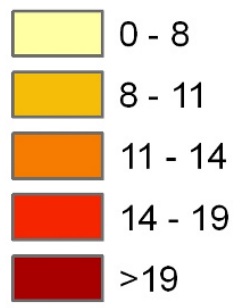

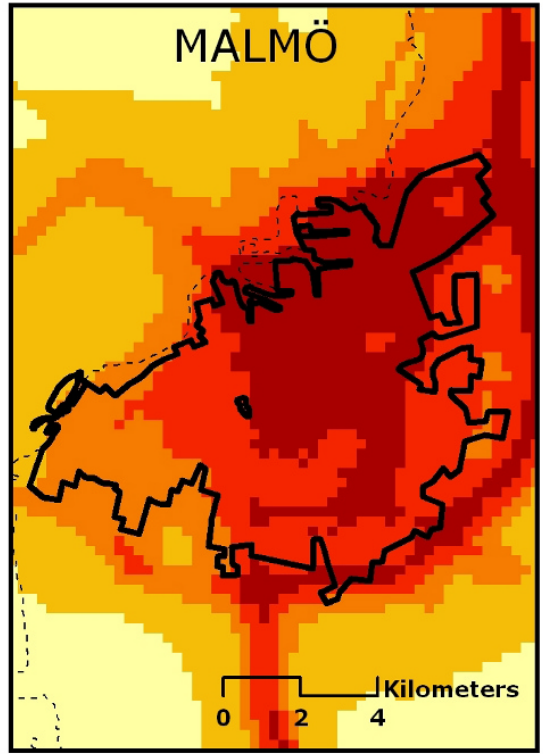

Figure 3

Modeled levels of $\mathrm{NO}_{x}$ Dispersion modeled annual average of $\mathrm{NO}_{x}$, modeled with a resolution of $250 \times 250 \mathrm{~m}$.

asthma symptoms among those living next to a road with at least 6 cars/minute, and higher prevalence of asthma diagnosis among those exposed to at least 10 cars/minute, compared with the group having no road within $100 \mathrm{~m}$. The effects seemed consistent, although statistically nonsignificant, across geographical region (tables 3, 4).

COPD and chronic bronchitis symptoms were associated with traffic intensity (table 5). However, when stratified geographically, the effect estimates indicated that chronic bronchitis symptoms were not associated with traffic intensity in Malmö (table 7).

\section{Association with $\mathrm{NO}_{x}$ at residential address}

Asthma symptoms, but not asthma diagnosis, were associated with $\mathrm{NO}_{\mathrm{x}}$ in the trend tests (table 2). However, effects were only seen in the highest quintile of $>19 \mu \mathrm{g} /$ $\mathrm{m}^{3}$. A geographical stratification showed that it was only in Malmö that high exposure was associated with asthma; no association was found in the region outside (tables 3 , 4).

COPD diagnosis and chronic bronchitis symptoms were associated with $\mathrm{NO}_{\mathrm{x}}$ (table 5). After geographical stratification, associations were seen only in Malmö, and not in the region outside (tables 6,7 ).

Stratification by smoking, sex, age, response group, and restricted analysis

In a stratified analysis, the effects of traffic exposure were more pronounced for smokers than for non-smokers, for both COPD (table 8) and bronchitis symptoms (data not shown). A test for interaction, however, showed no significance except for the interaction between smoking and road within $100 \mathrm{~m}$ for chronic bronchitis symptoms $(\mathrm{p}=$ 
Table I: Description of study population. Disease prevalence in relation to sex, age, and smoking.

\begin{tabular}{lllllll}
\hline & & $\mathrm{n}$ & Diagnosed asthma & Asthma symptoms & Diagnosed COPD & Chronic b. symptoms \\
\hline Sex & Men & 4341 & $258(5.9 \%)$ & $429(9.9 \%)$ & $172(4.0 \%)$ & $308(7.1 \%)$ \\
& Women & 4975 & $428(8.6 \%)$ & $686(13.8 \%)$ & $243(4.9 \%)$ & $327(6.6 \%)$ \\
Ever smoker & No & 4306 & $291(6.8 \%)$ & $431(10.0 \%)$ & $118(2.7 \%)$ & $217(5.0 \%)$ \\
& Yes & 5010 & $395(7.9 \%)$ & $684(13.7 \%)$ & $297(5.9 \%)$ & $418(8.3 \%)$ \\
Age & $18-19$ & 135 & $15(11.1 \%)$ & & & \\
& $20-29$ & 1062 & $110(10.4 \%)$ & $23(17 \%)$ & $3(2.2 \%)$ & $9(6.7 \%)$ \\
& $30-39$ & 2045 & $158(7.7 \%)$ & $246(12.0 \%)$ & $19(1.8 \%)$ & $41(3.9 \%)$ \\
& $40-49$ & 1887 & $112(5.9 \%)$ & $217(11.5 \%)$ & $69(3.7 \%)$ & $108(5.3 \%)$ \\
& $50-59$ & 2123 & $142(6.7 \%)$ & $237(11.2 \%)$ & $106(5.0 \%)$ & $101(5.4 \%)$ \\
& $60-69$ & 1586 & $113(7.1 \%)$ & $178(11.2 \%)$ & $115(7.3 \%)$ & $139(8.7 \%)$ \\
& $70-77$ & 478 & $36(7.5 \%)$ & $73(15.3 \%)$ & $42(8.8 \%)$ & $52(10.9 \%)$ \\
\hline
\end{tabular}

0.023). Asthma showed no indications of effect modification by smoking.

No effect modifications were seen when the data were stratified by sex, age, or sample group (new participants vs. follow-up group). Restriction of analysis to asthmatics without COPD, and to those with COPD without asthma, was performed for both diagnoses and symptoms. The results showed similar effects in the restricted and nonrestricted groups. The overlaps between the different disease outcome definitions are presented in table 9.

\section{Discussion}

Overall, residential traffic was associated with a higher prevalence of both asthma diagnosis and asthma symptoms in the last 12 months, as well as COPD diagnosis and chronic bronchitis symptoms. Traffic intensity on the heaviest road within $100 \mathrm{~m}$ showed effects at a traffic intensity of $>6$ cars/min. Effects from $\mathrm{NO}_{\mathrm{x}}$ were seen in the highest exposure quintile of $>19 \mu \mathrm{g} / \mathrm{m}^{3}$, but only in Malmö, not in the region outside.

\section{Discussion of exposure assessment}

The major strength of this study was the use of three different proxies of exposure, which may have different intrinsic strengths and weaknesses. The strengths of the $\mathrm{NO}_{\mathrm{x}}$ model are firstly that it reflects total traffic density in the area, and secondly the fact that the dispersion model has been validated, with a resolution of $250 \times 250 \mathrm{~m}$ showing a high correlation with measured background concentrations [25]. Nevertheless, street-level concentrations may vary on a much smaller scale. High peak concentrations are often found in so-called "street canyons" in urban areas, where pollutants are trapped between high buildings [23]. Since the dispersion model did not take account of this kind of accumulation effect, the true expo-

Table 2: Asthma diagnosis and asthma symptoms in relation to traffic.

\begin{tabular}{|c|c|c|c|c|c|c|c|}
\hline & & \multicolumn{3}{|c|}{ Asthma Diagnosis } & \multicolumn{3}{|c|}{ Asthma Symptoms } \\
\hline & & $\mathrm{n}$ & $\mathrm{n}(\%)$ & $\mathrm{OR}^{\mathrm{a}}$ & $\mathrm{n}$ & n (\%) & OR a \\
\hline \multirow[t]{2}{*}{ Heavy traffic } & No & 6041 & $400(6.6 \%)$ & 1.00 & 6041 & $668(11.1 \%)$ & 1.00 \\
\hline & Yes & 3275 & $286(8.7 \%)$ & $1.28(1.09-1.50)$ & 3275 & $447(13.6 \%)$ & $1.22(1.07-1.39)$ \\
\hline \multirow[t]{5}{*}{ Heaviest road within $<100 m$} & no heavy road & 3755 & $269(7.2 \%)$ & 1.00 & 3755 & $419(11.2 \%)$ & 1.00 \\
\hline & $<2 \mathrm{cars} / \mathrm{min}$ & 2235 & $149(6.7 \%)$ & $0.92(0.75-1.13)$ & 2235 & $263(11.8 \%)$ & $1.05(0.89-1.24)$ \\
\hline & $2-5 \mathrm{cars} / \mathrm{min}$ & 1820 & $134(7.4 \%)$ & $1.00(0.81-1.25)$ & 1820 & $216(11.9 \%)$ & $1.06(0.89-1.26)$ \\
\hline & $6-10 \mathrm{cars} / \mathrm{min}$ & 886 & $69(7.8 \%)$ & $1.05(0.79-1.38)$ & 886 & $126(14.2 \%)$ & $1.25(1.01-1.55)$ \\
\hline & $>10 \mathrm{cars} / \mathrm{min}$ & 578 & $61(10.6 \%)$ & $1.40(1.04-1.89)$ & 578 & $85(\mid 4.7 \%)$ & $1.29(1.00-1.67)$ \\
\hline \multirow[t]{6}{*}{$\mathrm{NO}_{\mathrm{x}}\left(\mu \mathrm{g} / \mathrm{m}^{3}\right)$} & $0-8$ & 1855 & $140(7.5 \%)$ & 1.00 & 1855 & $217(11.7 \%)$ & 1.00 \\
\hline & $8-11$ & 1855 & $146(7.9 \%)$ & $1.04(0.82-1.32)$ & 1855 & $213(11.5 \%)$ & $0.97(0.80-1.19)$ \\
\hline & $11-14$ & 1855 & $124(6.7 \%)$ & $0.85(0.66-1.09)$ & 1855 & $208(11.2 \%)$ & $0.94(0.77-1.15)$ \\
\hline & $14-19$ & 1858 & $115(6.2 \%)$ & $0.77(0.60-1.00)$ & 1858 & $206(11.1 \%)$ & $0.90(0.74-1.11)$ \\
\hline & $>19$ & $185 \mid$ & $157(8.5 \%)$ & $1.05(0.83-1.34)$ & $|85|$ & $265(14.3 \%)$ & $1.21(0.99-1.46)$ \\
\hline & & & $\mathrm{p}$-trend & 0.84 & & $\mathrm{p}$-trend & 0.026 \\
\hline
\end{tabular}

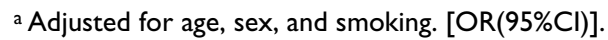


Table 3: Geographical stratification. Asthma diagnosis in the city of Malmö and the area outside.

\begin{tabular}{|c|c|c|c|c|c|c|c|}
\hline & & \multicolumn{3}{|c|}{ Malmö } & \multicolumn{3}{|c|}{ Region outside Malmö } \\
\hline & & $\mathrm{n}$ & Asthma diagnosis & $\mathrm{OR}^{\mathrm{a}}$ & $\mathrm{n}$ & Asthma diagnosis & $\mathrm{OR}^{\mathrm{a}}$ \\
\hline \multirow[t]{2}{*}{ Heavy traffic } & No & 1767 & $109(6.2 \%)$ & 1.00 & 4178 & $283(6.8 \%)$ & 1.00 \\
\hline & Yes & 1877 & $161(8.6 \%)$ & $1.35(1.05-1.75)$ & 1343 & $119(8.9 \%)$ & $1.28(1.02-1.61)$ \\
\hline \multirow[t]{5}{*}{ Heaviest road within $<100 m$} & no heavy road & 586 & $40(6.8 \%)$ & 1.00 & 3124 & $224(7.2 \%)$ & 1.00 \\
\hline & $<2 \mathrm{cars} / \mathrm{min}$ & 1021 & $66(6.5 \%)$ & $0.95(0.63-1.43)$ & 1193 & $82(6.9 \%)$ & $0.95(0.73-1.23)$ \\
\hline & $2-5 \mathrm{cars} / \mathrm{min}$ & 837 & $57(6.8 \%)$ & $0.99(0.65-\mid .5 I)$ & 961 & $75(7.8 \%)$ & $1.07(0.8 \mathrm{I}-\mathrm{I} .40)$ \\
\hline & $6-10 \mathrm{cars} / \mathrm{min}$ & 663 & $50(7.5 \%)$ & $1.12(0.72-1.72)$ & 212 & $19(9.0 \%)$ & $1.21(0.74-1.99)$ \\
\hline & $>10$ cars $/ \mathrm{min}$ & 537 & $57(10.6 \%)$ & $1.50(0.98-2.31)$ & 31 & 2 & - \\
\hline \multirow[t]{6}{*}{$\mathrm{NO}_{x}\left(\mu \mathrm{g} / \mathrm{m}^{3}\right)$} & $0-8$ & 13 & I & - & 1824 & $138(7.6 \%)$ & 1.00 \\
\hline & $8-11$ & 46 & 5 & - & 1792 & $138(7.7 \%)$ & $1.01(0.79-1.30)$ \\
\hline & $11-14$ & 562 & $39(6.9 \%)$ & 1.00 & 1268 & $83(6.5 \%)$ & $0.8 \mathrm{I}(0.6 \mathrm{I}-\mathrm{I} .08)$ \\
\hline & $14-19$ & 1325 & $76(5.7 \%)$ & $0.79(0.53-1.18)$ & 510 & $37(7.3 \%)$ & $0.93(0.64-1.36)$ \\
\hline & $>19$ & 1698 & $149(8.8 \%)$ & I.18(0.8I-I.7I) & 127 & $6(4.7 \%)$ & $0.58(0.25-1.34)$ \\
\hline & & & $\mathrm{p}$-trend & 0.044 & & p-trend & 0.079 \\
\hline
\end{tabular}

a Adjusted for age, sex, and smoking. [OR( $95 \% \mathrm{Cl})]$.

sure among people living in these surroundings might have been underestimated. This may partly explain why effects from $\mathrm{NO}_{\mathrm{x}}$ were seen in the urban city of Malmö but not in the surrounding area.

The proportion of $\mathrm{NO}_{\mathrm{x}}$ that originates from traffic is also dependent on geographical area. In urban areas of southern Sweden, local traffic contributes approximately 50$60 \%$ of total $\mathrm{NO}_{\mathrm{x}}$, while in the countryside such traffic is responsible for only $10-30 \%$ of total $\mathrm{NO}_{\mathrm{x}}$ (S. Gustafsson, personal communication, 2007-10-17). This difference was also reported by the SAPALDIA study, which found that local traffic accounted for the majority of $\mathrm{NO}_{\mathrm{x}}$ in urban but not rural areas [35]. This indicates that our model of $\mathrm{NO}_{\mathrm{x}}$ is a good proxy for exposure to trafficrelated air pollution in an urban area, but may not be sensitive enough to capture individual risk in the countryside, where traffic contributes to a lower proportion of total concentrations.

Self-reported living close to a road with heavy traffic, and traffic intensity on the heaviest road within $100 \mathrm{~m}$, are simple proxies; they do not reflect, for example, whether someone lives at a junction. Still, they have the advantage that they are less limited by aggregation in space than the $\mathrm{NO}_{\mathrm{x}}$ model. In the present study, both of these variables

Table 4: Geographical stratification. Asthma symptoms in the city of Malmö and the region outside.

\begin{tabular}{|c|c|c|c|c|c|c|c|}
\hline & & \multicolumn{3}{|c|}{ Malmö } & \multicolumn{3}{|c|}{ Region outside Malmö } \\
\hline & & $\mathrm{n}$ & Asthma symptoms & OR a & $\mathrm{n}$ & Asthma symptoms & OR a \\
\hline \multirow[t]{2}{*}{ Heavy traffic } & No & 1767 & $209(11.8 \%)$ & 1.00 & 4178 & $449(10.7 \%)$ & 1.00 \\
\hline & Yes & 1877 & $263(14.0 \%)$ & $1.17(0.96-1.43)$ & 1343 & $178(13.3 \%)$ & $1.23(1.02-1.49)$ \\
\hline \multirow[t]{5}{*}{ Heaviest road within $<100 \mathrm{~m}$} & No heavy road & 586 & $74(12.6 \%)$ & 1.00 & 3124 & $342(10.9 \%)$ & 1.00 \\
\hline & $<2 \mathrm{cars} / \mathrm{min}$ & 1021 & $119(11.7 \%)$ & $0.93(0.68-1.26)$ & 1193 & $142(|| .9 \%)$ & $1.09(0.88-1.34)$ \\
\hline & $2-5 \mathrm{cars} / \mathrm{min}$ & 837 & $101(12.1 \%)$ & $0.97(0.70-1.33)$ & 961 & II2(II.7\%) & $1.06(0.84-1.33)$ \\
\hline & $6-10 \mathrm{cars} / \mathrm{min}$ & 663 & $97(14.6 \%)$ & $1.17(0.85-1.63)$ & 212 & $29(13.7 \%)$ & I.24(0.82-I.87) \\
\hline & $>10 \mathrm{cars} / \mathrm{min}$ & 537 & $81(15.1 \%)$ & $1.19(0.84-1.68)$ & 31 & 2 & - \\
\hline \multirow[t]{6}{*}{$\mathrm{NO}_{x}\left(\mu \mathrm{g} / \mathrm{m}^{3}\right)$} & $0-8$ & 13 & 1 & - & 1824 & $215(11.8 \%)$ & 1.00 \\
\hline & $8-11$ & 46 & 6 & - & 1792 & $205(11.4 \%)$ & $0.96(0.79-1.18)$ \\
\hline & $11-14$ & 562 & $65(11.6 \%)$ & 1.00 & 1268 & $\mid 42(|| .2 \%)$ & $0.93(0.74-1.16)$ \\
\hline & $14-19$ & 1325 & $\mid 46(|| .0 \%)$ & $0.90(0.66-1.23)$ & 510 & $57(11.2 \%)$ & $0.95(0.69-1.29)$ \\
\hline & $>19$ & 1698 & $254(15.0 \%)$ & $1.28(0.95-1.72)$ & 127 & $8(6.3 \%)$ & $0.50(0.24-1.04)$ \\
\hline & & & P-trend & 0.002 & & P-trend & 0.344 \\
\hline
\end{tabular}

\footnotetext{
${ }^{a}$ Adjusted for age, sex, and smoking. [OR $\left.(95 \% \mathrm{Cl})\right]$.
} 
Table 5: COPD diagnosis and chronic bronchitis symptoms in relation to traffic.

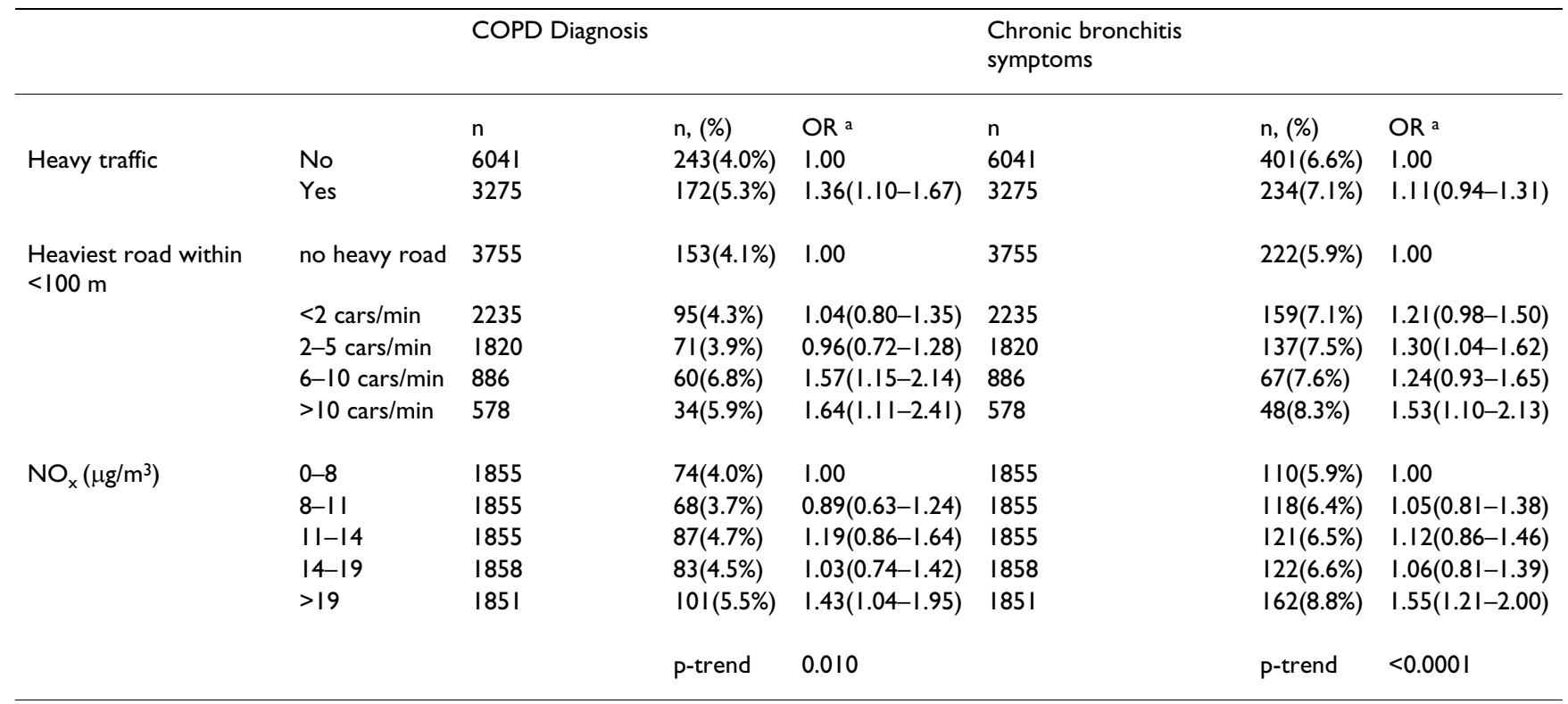

a Adjusted for age, sex, and smoking. [OR(95\%Cl)].

showed fairly consistent associations, at least with asthma, despite large differences in the level of $\mathrm{NO}_{\mathrm{x}}$ that they corresponded to in Malmö and the region outside (table 10); this may indicate that adverse effects from traffic pollutants are mainly seen in close proximity to traffic. High traffic intensity, however, may not only correlate with high total number of vehicles, but also with a higher proportion of heavy vehicles, an additional factor which could affect the outcome, since diesel exhaust from heavy vehicles might have more adverse respiratory effects [36].
It should be noted that the distribution of exposure is not comparable between the proxies. While $\mathrm{NO}_{\mathrm{x}}$ was divided into quintiles, with $20 \%$ in the highest exposure category, only $6 \%$ of the population lay in the highest traffic intensity category. Thus, the different proxies are complementary rather than comparable in this study.

One limitation of all three proxies of exposure was that traffic-related air pollution was only estimated by residential address. Lack of individual data about work address and time spent commuting could have biased the expo-

Table 6: Geographical stratification. COPD diagnosis in Malmö and the region outside.

\begin{tabular}{|c|c|c|c|c|c|c|c|}
\hline & & \multicolumn{3}{|c|}{ Malmö } & \multicolumn{3}{|c|}{ Region outside Malmö } \\
\hline & & $\mathrm{n}$ & COPD & OR a & $\mathrm{n}$ & COPD & OR a \\
\hline \multirow[t]{2}{*}{ Heavy traffic } & No & 1767 & $85(4.8 \%)$ & 1.00 & 4178 & $152(3.6 \%)$ & 1.00 \\
\hline & Yes & 1877 & $103(5.5 \%)$ & $1.24(0.92-1.67)$ & 1343 & $69(5.1 \%)$ & $1.47(1.09-1.97)$ \\
\hline \multirow[t]{5}{*}{ Heaviest road within $<100 m$} & no heavy road & 586 & $28(4.8 \%)$ & 1.00 & 3124 & $124(4.0 \%)$ & 1.00 \\
\hline & $<2$ cars $/ \mathrm{min}$ & 1021 & $44(4.3 \%)$ & $0.89(0.55-146)$ & 1193 & $49(4.1 \%)$ & $1.06(0.75-1.49)$ \\
\hline & $2-5 \mathrm{cars} / \mathrm{min}$ & 837 & $35(4.2 \%)$ & $0.89(0.53-1.48)$ & 961 & $35(3.6 \%)$ & $0.93(0.64-1.37)$ \\
\hline & $6-10 \mathrm{cars} / \mathrm{min}$ & 663 & $50(7.5 \%)$ & $1.53(0.95-2.48)$ & 212 & $10(4.7 \%)$ & $1.20(0.62-2.35)$ \\
\hline & $>10 \mathrm{cars} / \mathrm{min}$ & 537 & $31(5.8 \%)$ & I.34(0.79-2.28) & 31 & 3 & - \\
\hline \multirow[t]{6}{*}{$\mathrm{NO}_{x}\left(\mu \mathrm{g} / \mathrm{m}^{3}\right)$} & $0-8$ & 13 & 0 & - & 1824 & $72(3.9 \%)$ & 1.00 \\
\hline & $8-11$ & 46 & 2 & - & 1792 & $66(3.7 \%)$ & $0.90(0.64-1.27)$ \\
\hline & $11-14$ & 562 & $27(4.8 \%)$ & 1.00 & 1268 & $60(4.7 \%)$ & $1.26(0.89-1.80)$ \\
\hline & $14-19$ & 1325 & $64(4.8 \%)$ & $0.94(0.59-1.49)$ & 510 & $18(3.5 \%)$ & $0.91(0.54-1.55)$ \\
\hline & $>19$ & 1698 & $95(5.6 \%)$ & $1.23(0.79-1.92)$ & 127 & $5(3.9 \%)$ & I. $19(0.47-3.02)$ \\
\hline & & & p-trend & 0.142 & & p-trend & 0.421 \\
\hline
\end{tabular}

\footnotetext{
a Adjusted for age, sex, and smoking. [OR $(95 \% \mathrm{Cl})]$.
} 
Table 7: Geographical stratification. Chronic bronchitis symptoms in the city of Malmö and the area outside.

\begin{tabular}{|c|c|c|c|c|c|c|c|}
\hline & & \multicolumn{3}{|c|}{ Malmö } & \multicolumn{3}{|c|}{ Region outside Malmö } \\
\hline & & $\mathrm{n}$ & Chronic b. symptoms & $\mathrm{OR}^{\mathrm{a}}$ & $\mathrm{n}$ & Chronic b. symptoms & $\mathrm{OR}^{\mathrm{a}}$ \\
\hline \multirow[t]{2}{*}{ Heavy traffic } & No & 1767 & $150(8.5 \%)$ & 1.00 & 4178 & $246(5.9 \%)$ & 1.00 \\
\hline & Yes & 1877 & $140(7.5 \%)$ & $0.91(0.7 I-1.16)$ & 1343 & $92(6.9 \%)$ & $1.20(0.94-1.54)$ \\
\hline \multirow[t]{5}{*}{ Heaviest road within $<100 m$} & no heavy road & 586 & $43(7.3 \%)$ & 1.00 & 3124 & $179(5.7 \%)$ & 1.00 \\
\hline & $<2 \mathrm{cars} / \mathrm{min}$ & 1021 & $89(8.7 \%)$ & $1.21(0.83-1.77)$ & 1193 & $68(5.7 \%)$ & $1.00(0.75-1.34)$ \\
\hline & $2-5 \mathrm{cars} / \mathrm{min}$ & 837 & $66(7.9 \%)$ & $1.10(0.73-1.64)$ & 961 & $69(7.2 \%)$ & $1.30(0.98-1.74)$ \\
\hline & $6-10 \mathrm{cars} / \mathrm{min}$ & 663 & $47(7.1 \%)$ & $0.94(0.61-1.45)$ & 212 & $19(9.0 \%)$ & $1.63(0.99-2.69)$ \\
\hline & $>10 \mathrm{cars} / \mathrm{min}$ & 537 & $45(8.4 \%)$ & $1.22(0.78-1.89)$ & 31 & 3 & - \\
\hline \multirow[t]{6}{*}{$\mathrm{NO}_{\mathrm{x}}\left(\mu \mathrm{g} / \mathrm{m}^{3}\right)$} & $0-8$ & 13 & 0 & - & 1824 & $109(6.0 \%)$ & 1.00 \\
\hline & $8-11$ & 46 & 4 & - & 1792 & $113(6.3 \%)$ & $1.04(0.79-1.37)$ \\
\hline & $11-14$ & 562 & $35(6.2 \%)$ & 1.00 & 1268 & $84(6.6 \%)$ & $1.17(0.87-1.57)$ \\
\hline & $14-19$ & 1325 & $96(7.2 \%)$ & $1.13(0.76-1.70)$ & 510 & $26(5.1 \%)$ & $0.88(0.57-1.37)$ \\
\hline & $>19$ & 1698 & $155(9.1 \%)$ & $1.57(1.06-2.30)$ & 127 & $6(4.7 \%)$ & $0.86(0.37-2.01)$ \\
\hline & & & $\mathrm{p}$-trend & 0.017 & & $\mathrm{p}$-trend & 0.541 \\
\hline
\end{tabular}

a Adjusted for age, sex, and smoking. [OR(95\% Cl)].

sure assessments, particularly for people living in areas with low exposure to traffic-related air pollution, where individual differences in daily activities outside the residential area translate to a large proportion of total exposure [37]. In Los Angeles, $1 \mathrm{~h}$ commuting/day contributes approximately $10-50 \%$ of people's daily exposure to ultrafine particles from traffic [38]. While only $20 \%$ of the working population living in Malmö commute to work outside Malmö, the majority of the population in smaller municipalities in the remaining region commute to work outside their own municipality [39].
Another limitation was the cross-sectional nature of the study; we had no information about disease onset or years living at current address, making it hard to establish a temporal relationship between cause and effect. However, since asthma and COPD are known to be exacerbated by traffic-related air pollution, subjects with disease may have been more likely to move away from traffic, rather than towards it, and so a migrational bias would mainly be expected to dilute the effects.

Table 8: Stratification on smoking. COPD diagnosis in relation to traffic among smokers/ex-smokers and non-smokers.

\begin{tabular}{|c|c|c|c|c|c|c|c|}
\hline & & \multicolumn{3}{|c|}{ Smokers/ex-smokers } & \multicolumn{3}{|c|}{ Non-smokers } \\
\hline & & $\mathrm{n}$ & COPD D & $\mathrm{OR}^{\mathrm{a}}$ & $\mathrm{n}$ & COPD D & $\mathrm{OR}^{\mathrm{a}}$ \\
\hline \multirow[t]{2}{*}{ Heavy traffic } & No & 3149 & $167(5.3 \%)$ & 1.00 & 2892 & $76(2.6 \%)$ & 1.00 \\
\hline & Yes & $|86|$ & $130(7.0 \%)$ & $1.43(1.13-1.82)$ & 1414 & $42(3.0 \%)$ & $1.19(0.81-1.76)$ \\
\hline \multirow[t]{5}{*}{ Heaviest road within $<100 m$} & no heavy road & 1951 & $104(5.3 \%)$ & 1.00 & 1804 & $49(2.7 \%)$ & 1.00 \\
\hline & $<2 \mathrm{cars} / \mathrm{min}$ & 1185 & $67(5.7 \%)$ & I.06(0.77-1.45) & 1050 & $28(2.7 \%)$ & $0.99(0.62-1.59)$ \\
\hline & $2-5 \mathrm{cars} / \mathrm{min}$ & 992 & $52(5.2 \%)$ & $0.99(0.70-1.40)$ & 828 & $19(2.3 \%)$ & $0.88(0.5 \mathrm{I}-1.5 \mathrm{I})$ \\
\hline & $6-10 \mathrm{cars} / \mathrm{min}$ & 522 & $44(8.4 \%)$ & $1.56(1.08-2.26)$ & 364 & $16(4.4 \%)$ & $1.64(0.92-2.94)$ \\
\hline & $>10 \mathrm{cars} / \mathrm{min}$ & 344 & $28(8.1 \%)$ & $1.84(1.18-2.86)$ & 234 & $6(2.6 \%)$ & $1.15(0.48-2.75)$ \\
\hline \multirow[t]{5}{*}{$\mathrm{NO}_{x}\left(\mu \mathrm{g} / \mathrm{m}^{3}\right)$} & $0-8$ & 969 & $47(4.9 \%)$ & 1.00 & 886 & $27(3.0 \%)$ & 1.00 \\
\hline & $8-11$ & 971 & $47(4.8 \%)$ & $0.96(0.63-1.46)$ & 884 & $21(2.4 \%)$ & $0.77(0.43-1.37)$ \\
\hline & $|1-| 4$ & 945 & $63(6.7 \%)$ & $1.35(0.92-2.00)$ & 910 & $24(2.6 \%)$ & $0.92(0.52-1.61)$ \\
\hline & $14-19$ & 1037 & $60(5.8 \%)$ & I. $14(0.92-2.00)$ & 821 & $23(2.8 \%)$ & $0.85(0.48-1.50)$ \\
\hline & $>19$ & 1072 & $78(7.3 \%)$ & $1.61(1.11-2.35)$ & 779 & $23(3.0 \%)$ & $1.12(0.63-1.98)$ \\
\hline Test för & \multicolumn{3}{|c|}{ Heavy traffic*eversmoker } & $p=0.47$ & & & \\
\hline \multirow[t]{2}{*}{ Interaction } & \multicolumn{3}{|c|}{ Heaviestroad 100 m*eversmoker } & $p=0.89$ & & & \\
\hline & \multicolumn{3}{|c|}{ NOx*eversmoker } & $p=0.83$ & & & \\
\hline
\end{tabular}

a Adjusted for age and sex. [OR(95\%Cl)]. 
Table 9: Description of overlap between the different reported disease outcomes. Percentage within row. The first row shows that $70 \%$ of those with asthma diagnosis had asthma symptoms, $20 \%$ of those with asthma diagnosis had COPD diagnosis, and $21 \%$ of those with asthma diagnosis had chronic bronchitis symptoms.

\begin{tabular}{llllll}
\hline & Total $\mathrm{n}$ & Asthma diagnosis $\mathrm{n}(\%)$ & Asthma symptoms $\mathrm{n}(\%)$ & COPD diagnosis $\mathrm{n}(\%)$ & Chronic b. Symptoms (n \%) \\
\hline Asthma diagnosis & 686 & - & $483(70 \%)$ & $139(20 \%)$ & $145(21 \%)$ \\
Asthma symptoms & 1115 & $483(43 \%)$ & - & $219(20 \%)$ & $277(25 \%)$ \\
COPD diagnosis & 415 & $139(34 \%)$ & $219(53 \%)$ & - & $152(37 \%)$ \\
Chronic bronchitis symptoms & 635 & $145(23 \%)$ & $277(44 \%)$ & $152(24 \%)$ & - \\
\hline
\end{tabular}

\section{Discussion of potential confounding}

Areas with high levels of exposure to traffic-related air pollution were mainly located in the city of Malmö (table 4 and figure 2), while low exposure was found in more sparsely populated areas. It is a well recognized problem that the different exposure levels in rural and urban environments are also accompanied by large differences in lifestyle factors, and even if confounders are controlled for, unmeasured factors may remain. Since $\mathrm{NO}_{\mathrm{x}}$ was limited by its spatial resolution, it is also the measure that was most susceptible to ecological bias. The lack of association seen with $\mathrm{NO}_{x^{\prime}}$ in the region outside Malmö might thus reflect that the individual risk from traffic is being overridden by some other factor correlating with low exposure levels. The existence of independent risk factors correlating with low exposure is given some support by a Swedish study which found a tendency to higher adult asthma incidence in rural areas, after adjustment for exposure to traffic [11].

The most important risk factors from a validity standpoint, however, are factors that could correlate with high exposure to traffic-related air pollution, and thus cause a false positive relationship, such as socio-economic and occupational risk factors. However, the present study, which used individual-level data, found no confounding effects for either socio-economic status or occupational exposure. A recently developed and validated JEM was used to adjust for occupational exposure [33]. In a JEM, people are assigned the statistically average level of exposure in their occupation; this is an aggregated form of exposure assessment that can suffer from misclassification bias, although non-differential to disease. Since we only had information on the participants' current occupations, we cannot rule out the possibility of a "healthy worker effect". Lack of information about occupational history may be a limitation, especially in relation to the prevalence of COPD/chronic bronchitis.

\section{Results discussion}

Although asthma and COPD have many risk factors in common and often coexist in clinical settings, and there is some evidence that asthma may be a risk factor for the development of COPD [40], they are distinct conditions, with differing clinical course and pathological features. Thus, inconsistencies between studies in the relation between air pollution and asthma/COPD could depend both on the presence of different competing risk factors,

Table 10: Relation between the exposure proxies and modeled $\mathrm{NO}_{x}\left(\mu \mathrm{g} / \mathrm{m}^{3}\right)$ as a continuous variable.

\begin{tabular}{|c|c|c|c|c|c|c|c|c|c|}
\hline & & \multicolumn{4}{|c|}{ Malmö $\mathrm{NO}_{x}$} & \multicolumn{4}{|c|}{ Region outside Malmö $\mathrm{NO}_{\mathrm{x}}$} \\
\hline & & $\mathrm{n}$ & Mean & $\mathrm{SD}$ & Median & $\mathrm{n}$ & Mean & $\mathrm{SD}$ & Median \\
\hline \multirow[t]{2}{*}{ Heavy traffic } & No & 1507 & 18.0 & 3.1 & 17.4 & 4502 & 10.2 & 3.5 & 9.6 \\
\hline & Yes & 1772 & 19.6 & 3.2 & 19.6 & 1495 & 12.1 & 4.5 & 11.4 \\
\hline \multirow[t]{5}{*}{ Heaviest road within $<100 \mathrm{~m}$} & no heavy road & 488 & 17.6 & 3.4 & 17.2 & 3267 & 10.1 & 3.4 & 9.6 \\
\hline & $<2$ cars/min & 855 & 18.0 & 2.9 & 17.8 & 1380 & 9.8 & 4.3 & 8.1 \\
\hline & $2-5 \mathrm{cars} / \mathrm{min}$ & 746 & 18.9 & 3.3 & 19.4 & 1074 & 12.6 & 3.8 & 11.5 \\
\hline & $6-10 \mathrm{cars} / \mathrm{min}$ & 627 & 18.1 & 2.8 & 17.4 & 259 & 13.8 & 2.3 & 14.03 \\
\hline & $>10 \mathrm{cars} / \mathrm{min}$ & 561 & 21.9 & 2.0 & 22.0 & 17 & 19.2 & 4.4 & 21.6 \\
\hline \multirow[t]{6}{*}{$\mathrm{NO}_{\mathrm{x}}\left(\mu \mathrm{g} / \mathrm{m}^{3}\right)$} & $0-8$ & 13 & 6.8 & 1.3 & 6.8 & 1824 & 6.7 & I.I & 6.8 \\
\hline & $8-11$ & 46 & 10.4 & 0.8 & 9.6 & 1792 & 9.9 & 0.8 & 10.0 \\
\hline & $11-14$ & 562 & 13.5 & 0.7 & 13.7 & 1268 & 12.8 & 1.0 & 12.7 \\
\hline & $14-19$ & 1325 & 16.7 & 1.3 & 15.9 & 510 & 15.7 & 1.2 & 15.3 \\
\hline & $>19$ & 1698 & 21.7 & 1.3 & 21.5 & 127 & 21.9 & 3.8 & 21.2 \\
\hline & Total & 3644 & 18.4 & 3.6 & 18.5 & 5521 & 10.31 & 3.6 & 10.04 \\
\hline
\end{tabular}


and on geographically different pollution mixtures acting on different regions of the respiratory tract. It is therefore important to consider local pollution characteristics as thoroughly as possible (tables 11, 12). When using traffic intensity or self-reported traffic exposure as a proxy, there is a lack of knowledge of the exact pollution compounds that this exposure represents. One known characteristic of traffic-related pollution in the study region is a large amount of wear particles from road-tire interaction. These particles have been shown to be potent inducers of local inflammation [41,42], and their levels are high in the Scandinavian countries due to the use of traction sand and studded tires.

Although levels of traffic pollution in Sweden are lower than those found in most other countries, the results for asthma are basically supported by some European studies with higher exposure levels. An Italian study reported an association between symptom exaggeration of adult asthma and $\mathrm{NO}_{2}$ exposure levels [12], and the Swiss SAPALDIA study observed an increase of asthma-related symptoms, although not current asthma, in relation to $\mathrm{NO}_{2}$ [43]. The European ECRHS study found a positive association between $\mathrm{NO}_{2}$ (modeled with a resolution of 1 $\mathrm{km}$ ) and asthma incidence, but effect estimates seemed very heterogenous among the Swedish centers (although overall heterogeneity tested was non-significant). [15]. Most relevantly, a Swedish study found a non-significant tendency to increased asthma incidence among adults living close to traffic flows, and measured $\mathrm{NO}_{2}$ levels comparable to those found in the present study [11]. Another study of asthma symptoms in Sweden found a significant but weak relation to $\mathrm{NO}_{2}[44]$, although a stronger relation was found with self-reported measures of traffic. The findings in the present study, support the existence of a relation between exposure to traffic-related air pollution and asthma in adults at relatively low levels of trafficrelated air pollution.

For COPD, a German study restricted to women found that COPD as defined by the GOLD criteria was 1.79 times more likely (95\% CI 1.06-3.02) for those living less than $100 \mathrm{~m}$ from a road with 10000 cars/day, than for those living farther away [19]. This is in agreement with our results, which found effects for living less than $100 \mathrm{~m}$ from a road with 6 cars/min (8 640 cars/day).

The European ECRHS study found that new onset of chronic bronchitis, as defined by chronic phlegm, was related among females to both self-reported traffic inten-

Table II: Urban background. Descriptive data of regional air pollution at a monitoring station in Malmö. Annual mean concentrations of traffic-related pollutants measured at Rådhuset Malmö 1980-2006. Data source: IVL Swedish Environmental Research Institute Ltd. http://www.ivl.se/miljo/

\begin{tabular}{|c|c|c|c|c|c|}
\hline Year & $\mathrm{SO}_{2}\left(\mu \mathrm{g} / \mathrm{m}^{3}\right)$ & $\mathrm{NO}_{2}\left(\mu \mathrm{g} / \mathrm{m}^{3}\right)$ & $\mathrm{O}_{3}\left(\mu \mathrm{g} / \mathrm{m}^{3}\right)$ & $\mathrm{PM}_{10}\left(\mu \mathrm{g} / \mathrm{m}^{3}\right)$ & $\mathrm{PM}_{2.5}\left(\mu \mathrm{g} / \mathrm{m}^{3}\right)$ \\
\hline 1980* & 49 & & & & \\
\hline 1981 & 50 & & & & \\
\hline 1982 & 43 & & & & \\
\hline 1983 & 33,1 & & & & \\
\hline 1984 & 22,9 & 42 & & & \\
\hline 1985 & 20,3 & 39 & & & \\
\hline 1986 & 16,7 & 31 & & & \\
\hline 1987 & 20,3 & 32 & & & \\
\hline 1988 & 13 & 30.5 & & & \\
\hline 1989 & 12 & 26.9 & 46 & & \\
\hline 1990 & 9 & 21.3 & 39 & & \\
\hline 1991 & 8 & 19.6 & 41 & & \\
\hline 1992 & 7 & 22.4 & 43 & & \\
\hline 1993 & 8 & 25.6 & 40 & & \\
\hline 1994 & 6 & 21.4 & 43 & & \\
\hline 1995 & 6 & 22 & 50 & & \\
\hline 1996 & 8 & 24.6 & 50 & 17.4 & \\
\hline 1997 & 5 & 26.2 & 48 & 17.6 & \\
\hline 1998 & 4 & 21.8 & 47 & 15.2 & \\
\hline 1999 & 4 & 23.5 & 50 & 15.8 & 12.6 \\
\hline 2000 & 2 & 22.9 & 49 & 16.5 & 13.5 \\
\hline 2001 & 2 & 21.1 & 46 & 18.7 & 12 \\
\hline 2002 & 2 & 20.3 & 52 & 18.1 & 11.5 \\
\hline 2003 & 3 & 20.8 & 49 & 21.6 & 13.7 \\
\hline 2004 & 3 & 19.5 & 54 & 15.9 & 10 \\
\hline 2005 & 4 & 20.6 & 49 & 17.5 & II.I \\
\hline 2006 & 3 & 19.3 & 52 & 18.2 & 12.3 \\
\hline
\end{tabular}


Table I2: Rural background. Descriptive data of regional air pollution at a monitoring station in a rural area. Annual mean concentrations of traffic-related pollutants measured at Vavihill 1985-2006. Data source: IVL Swedish Environmental Research Institute Ltd. http://www.ivl.se/miliol

\begin{tabular}{lllll}
\hline Year & $\mathrm{SO}_{2}\left(\mu \mathrm{g} / \mathrm{m}^{3}\right)$ & $\mathrm{NO}_{2}\left(\mu \mathrm{g} / \mathrm{m}^{3}\right)$ & $\mathrm{O}_{3^{\prime}}\left(\mu \mathrm{g} / \mathrm{m}^{3}\right)$ & $\mathrm{PM}_{10}\left(\mu \mathrm{g} / \mathrm{m}^{3}\right)$ \\
\hline 1985 & 5.14 & 2.36 & 60.2 & \\
1986 & & 2.27 & 59.9 & \\
1987 & 5.47 & 2.11 & 55.1 & \\
1988 & 3.90 & 1.84 & 57.7 & \\
1989 & 3.93 & 2.66 & 56.5 & \\
1990 & 2.98 & 2.36 & 55.0 & \\
1991 & 2.64 & 2.08 & 51.3 & \\
1992 & 2.06 & 1.72 & 56.0 & \\
1993 & 1.70 & 1.98 & 57.4 & \\
1994 & 1.17 & 1.78 & 58.6 & \\
1995 & 1.35 & 1.92 & 59.3 & 16.0 \\
1996 & 1.31 & 1.77 & 63.0 & 15.4 \\
1997 & 0.67 & 2.05 & 58.8 & 16.3 \\
1998 & 0.74 & 1.87 & 54.6 & 18.6 \\
1999 & 0.55 & 1.66 & 59.1 & 13.8 \\
2000 & 0.45 & 1.70 & 57.6 & 15.2 \\
2001 & 0.42 & 1.37 & 60.2 & 17.3 \\
2002 & 0.37 & 1.39 & 66.6 & \\
2003 & 0.52 & 1.54 & 62.9 & \\
2004 & 0.37 & 1.48 & 58.5 & \\
2005 & 0.49 & 1.47 & 61.0 & \\
2006 & 0.50 & 1.59 & & \\
\end{tabular}

sity (constant traffic vs. none, OR $=1.86 ; 95 \%$ CI 1.24 to 2.77) and home outdoor $\mathrm{NO}_{2}\left(\mathrm{OR}=50 \mu \mathrm{g} / \mathrm{m}^{3} \mathrm{vs} .20 \mu \mathrm{g} /\right.$ $\mathrm{m}^{3}=2.71 ; 95 \%$ CI 1.03 to 7.16 ) [20]. The higher levels of $\mathrm{NO}_{2}$ seen in the ECRHS study may partly stem from truly higher concentrations, but may also have been affected by the use of home outdoor measurements, which are better than our models at capturing locally high peak exposures. Other studies have suggested an effect modification for sex, with women being at higher risk, but this was not observed in our study. Our results did indicate effect modification by smoking, but tests for interaction were mainly non-significant. No interaction with smoking was found in any of the abovementioned studies of the effects of air pollution on prevalence/incidence of COPD in adults.

Overall, our results show that traffic-related air pollution is associated with the prevalence of COPD/chronic bronchitis in adults, but there is still a need for further investigation of the reasons behind the inconsistencies seen when the data were stratified by region.

\section{Conclusion}

Residential traffic is associated with both current symptoms and prevalence of diagnosis of asthma and COPD/ chronic bronchitis, among adults in southern Sweden. This may indicate that traffic has not only short-term but also long-term effects on adult chronic respiratory disease, even in a region with low overall levels of traffic pollution.

\section{Competing interests}

The authors declare that they have no competing interests.

\section{Authors' contributions}

AL: Conducted the statistical analyses and wrote the main part of the manuscript. ES: Performed GIS analyses and wrote part of the manuscript. PM: Designed and conducted the survey and made revisions on drafts. UN: Designed and conducted the survey and made revisions on drafts. KJ: Designed the study and made revisions on drafts. AA: Wrote part of the manuscript and made major revisions of drafts. All authors read and approved the final manuscript.

\section{Acknowledgements}

The authors would like to acknowledge Susanna Gustafsson and Håkan Tinnerberg, for providing valuable comments. Hans Kromhout provided the ALOHA job-exposure matrix. The study was supported by grants from the Swedish Environmental Protection Agency, the Swedish Emission Research Program, and the Faculty of Medicine at Lund University.

\section{References}

I. Halonen JI, Lanki T, Yli-Tuomi T, Kulmala M, Tiittanen P, Pekkanen J: Urban Air Pollution And Asthma And Copd Hospital Emergency Room Visits. Thorax 2008, 63(7):635-4I.

2. Kim Jj, Huen K, Adams S, Smorodinsky S, Hoats A, Malig B, Lipsett M, Ostro $B$ : Residential traffic and children's respiratory health. Environ Health Perspect 2008, I I 6(9): I 274-9.

3. Brauer M, Hoek G, Van Vliet P, Meliefste K, Fischer PH, Wijga A, Koopman LP, Neijens HJ, Gerritsen J, Kerkhof M, Heinrich J, Bellander T, Brunekreef B: Air pollution from traffic and the development of respiratory infections and asthmatic and allergic 
symptoms in children. Am J Respir Crit Care Med 2002, 166(8): 1092-8.

4. Morgenstern V, Zutavern A, Cyrys J, Brockow I, Gehring U, Koletzko S, Bauer CP, Reinhardt D, Wichmann HE, Heinrich J: Respiratory health and individual estimated exposure to traffic-related air pollutants in a cohort of young children. Occup Environ Med 2007, 64(I):8-16.

5. Brauer M, Hoek G, Smit HA, de Jongste JC, Gerritsen J, Postma DS, Kerkhof M, Brunekreef B: Air pollution and development of asthma, allergy and infections in a birth cohort. Eur Respir J 2007, 29(5):879-88.

6. Morgenstern V, Zutavern A, Cyrys J, Brockow I, Koletzko S, Krämer $\mathrm{U}$, Behrendt $\mathrm{H}$, Herbarth O, von Berg A, Bauer CP, Wichmann HE, Heinrich J, GINI Study Group; LISA Study Group: Am J Respir Crit Care Med 2008, I77(I 2): 1331-7.

7. Jerrett M, Shankardass K, Berhane K, Gauderman WJ, Künzli N, Avol E, Gilliland F, Lurmann F, Molitor JN, Molitor JT, Thomas DC, Peters J, McConnell R: Traffic-related air pollution and asthma onset in children: a prospective cohort study with individual exposure measurement. Environ Health Perspect 2008, I I 6( I 0): I 433-8.

8. Gauderman WJ, Vora H, McConnell R, Berhane K, Gilliland F, Thomas D, Lurmann F, Avol E, Kunzli N, Jerrett M, Peters J: Effect of exposure to traffic on lung development from 10 to 18 years of age: a cohort study. Lancet 2007, 369(956 I):57I-7.

9. Oftedal B, Brunekreef B, Nystad W, Madsen C, Walker SE, Nafstad $\mathrm{P}$ : Residential outdoor air pollution and lung function in schoolchildren. Epidemiology 2008, 19(1):129-37.

10. Viegi G, Maio S, Pistelli F, Baldacci S, Carrozzi L: Epidemiology of chronic obstructive pulmonary disease: health effects of air pollution. Respirology 2006, II (5):523-32.

II. Modig L, Järvholm B, Rönnmark E, Nyström L, Lundbäck B, Andersson C, Forsberg B: Vehicle exhaust exposure in an incident case-control study of adult asthma. Eur Respir J 2006, 28(I):75-8I.

12. de Marco R, Poli A, Ferrari M, Accordini S, Giammanco G, Bugiani M, Villani S, Ponzio M, Bono R, Carrozzi L, Cavallini R, Cazzoletti L, Dallari R, Ginesu F, Lauriola P, Mandrioli P, Perfetti L, Pignato S, Pirina P, Struzzo P, ISAYA study group: Italian Study on Asthma in Young Adults, The impact of climate and traffic-related NO2 on the prevalence of asthma and allergic rhinitis in Italy. Clin Exp Allergy 2002, 32(10): I 405-12.

13. Cesaroni G, Badaloni C, Porta D, Forastiere F, Perucci CA: Comparison between several indices of exposure to traffic-related air pollution and their respiratory health impact in adults. Occup Environ Med 2008.

14. Montnémery P, Bengtsson P, Elliot A, Lindholm LH, Nyberg P, Löfdahl $C G$ : Prevalence of obstructive lung diseases and respiratory symptoms in relation to living environment and socio-economic group. Respir Med 200I, 95(9):744-52.

15. Jacquemin B, Sunyer J, Forsberg B, Aguilera I, Briggs D, García-Esteban R, Götschi T, Heinrich J, Järvholm B, Jarvis D, Vienneau D, Künzli N: Home Outdoor NO2 and New Onset of Self-Reported Asthma in Adults. Epidemiology 2008 in press.

16. Heinrich J, Topp R, Gehring U, Thefeld W: Traffic at residential address, respiratory health, and atopy in adults: the National German Health Survey 1998. Environ Res 2005, 98(2):240-9.

17. Wyler C, Braun-Fahrländer C, Künzli N, Schindler C, Ackermann-Liebrich U, Perruchoud AP, Leuenberger P, Wüthrich B: Exposure to motor vehicle traffic and allergic sensitization. The Swiss Study on Air Pollution and Lung Diseases in Adults (SAPALDIA) Team. Epidemiology 2000, I I (4):450-6.

18. Zemp E, Elsasser S, Schindler C, Künzli N, Perruchoud AP, Domenighetti G, Medici T, Ackermann-Liebrich U, Leuenberger P, Monn C, Bolognini G, Bongard JP, Brändli O, Karrer W, Keller R, Schöni MH, Tschopp JM, Villiger B, Zellweger JP: Long-term ambient air pollution and respiratory symptoms in adults (SAPALDIA study). The SAPALDIA Team. Am J Respir Crit Care Med 1999, I59(4 Pt I): 1257-66

19. Schikowski T, Sugiri D, Ranft U, Gehring U, Heinrich J, Wichmann HE, Krämer U: Long-term air pollution exposure and living close to busy roads are associated with COPD in women. Respir Res 2005, 6:152

20. Sunyer J, Jarvis D, Gotschi T, Garcia-Esteban R, Jacquemin B, Aguilera I, Ackerman U, de Marco R, Forsberg B, Gislason T, Heinrich J, Norbäck D, Villani S, Künzli N: Chronic bronchitis and urban air pol- lution in an international study. Occup Environ Med 2006, 63(12):836-43.

21. Forastiere F, Galassi C: Self report and GIS based modelling as indicators of air pollution exposure: is there a gold standard? Occup Environ Med 2005, 62(8):508-9.

22. Zhou Y, Levy Jl: Factors influencing the spatial extent of mobile source air pollution impacts: a meta-analysis. $B M C$ Public Health 2007, 7:89.

23. Kirby C, Greig A, Drye T: Temporal and Spatial Variations in Nitrogen Dioxide Concentrations Across an Urban Landscape: Cambridge, UK. Environmental Monitoring and Assessment 1998, 52:65-82.

24. Salam MT, Islam T, Gilliland FD: Recent evidence for adverse effects of residential proximity to traffic sources on asthma. Curr Opin Pulm Med 2008, I 4(I):3-8.

25. Gustafsson S: Uppbyggnad och validering av emissionsdatabas avseende luftföroreningar för Skåne med basår 200 I [A geographical and temporal high resolution emission database for dispersion modelling of environmental NOX in Southern Sweden.]. The Department of Physical Geography and Ecosystem Analysis. In Swedish, english summary 2007 [http://www.med.lu.se/content/ download/27330/192790/file/Susanna Gustafsson lic.pdf]. Lund University: Lund

26. Kunzli N, Tager IB: Long-term health effects of particulate and other ambient air pollution: research can progress faster if we want it to. Environ Health Perspect 2000, 108(I0):915-8.

27. Stroh E, Oudin A, Gustafsson S, Pilesjö P, Harrie L, Strömberg U, Jakobsson K: Are associations between socio-economic characteristics and exposure to air pollution a question of study area size? An example from Scania, Sweden. Int J Health Geogr 2005, 4:30.

28. Sjöberg, Luftkvalitet i tätorter 2005. IVL [Swedish Environmental Research Institute]: Stockholm 2006.

29. Nihlén U, Montnémery P, Andersson M, Persson CG, Nyberg P, Löfdahl CG, Greiff L: Specific nasal symptoms and symptom-provoking factors may predict increased risk of developing COPD. Clin Physiol Funct Imaging 2008, 28(4):240-50.

30. Vägverket, NVDB Nationell vägdatabas [The Swedish national road database] 2007 [http://www.vv.se/nvdb/].

31. Stroh E: The use of GIS in Exposure-Response Studies, in The Department of Physical Geography and Ecosystem Analysis. 2006 [http://www.med.lu.se/content/download/27331//92793/file/ Emilie Stroh lic.pdf]. Lund University: Lund

32. Statistics-Sweden, The Socio-economic Classification of Occupation. Stockholm. 1982.

33. Matheson MC, Benke G, Raven J, Sim MR, Kromhout H, Vermeulen R, Johns DP, Walters EH, Abramson MJ: Biological dust exposure in the workplace is a risk factor for chronic obstructive pulmonary disease. Thorax 2005, 60(8):645-5।.

34. Greenland : Modeling and variable selection in epidemiologic analysis. American Journal of Public Health 1989, 79(3):340-349.

35. Liu SL-JC, Keidel D, Heldstab J, Kûnzli N, Bayer-Oglesby L, Ackermann-Liebrich U, Schindler C, the SAPALDIA team: Characterization of Source-Specific Air Pollution Exposure for a Large Population-Based Swiss Cohort (SAPALDIA). Environmental Health Perspectives 2007.

36. Brunekreef $B$, Janssen NA, de Hartog J, Harssema H, Knape M, van Vliet $P$ : Air pollution from truck traffic and lung function in children living near motorways. Epidemiology 1997, 8(3):298-303.

37. Berhane KGW, Stram OD, Duncan TC: Statistical Issues in Strudies of the Long-Term Effects of Air Pollution: The Southern California Children's Health Study. Statistical Science 2004, 19(3):414-449.

38. Zhu Y, Eiguren-Fernandez A, Hinds WC, Miguel AH: In-cabin commuter exposure to ultrafine particles on Los Angeles freeways. Environ Sci Technol 2007, 4 I(7):2138-45.

39. Statistics-Sweden TableAndChart 23020.aspx]

[http://www.scb.se/Pages/

40. Mannino DM, Buist AS: Global burden of COPD: risk factors, prevalence, and future trends. Lancet 2007, 370(9589):765-73.

41. Lindbom J, Gustafsson M, Blomqvist G, Dahl A, Gudmundsson A, Swietlicki $E$, Ljungman AG: Wear particles generated from studded tires and pavement induces inflammatory reactions in mouse macrophage cells. Chem Res Toxicol 2007, 20(6):937-46. 
42. Gustafsson M, Blomqvist G, Gudmundsson A, Dahl A, Swietlicki E, Bohgard M, Lindbom J, Ljungman A: Properties and toxicological effects of particles from the interaction between tyres, road pavement and winter traction material. Sci Total Environ 2008, 393(2-3):226-40.

43. Bayer-Oglesby L, Schindler C, Hazenkamp-von Arx ME, Braun-Fahrländer C, Keidel D, Rapp R, Künzli N, Braendli O, Burdet L, Sally Liu LJ, Leuenberger P, Ackermann-Liebrich U, SAPALDIA Team: Living near main streets and respiratory symptoms in adults: the Swiss Cohort Study on Air Pollution and Lung Diseases in Adults. Am J Epidemiol 2006, I64(I 2): I 190-8.

44. Modig L, Forsberg B: Perceived annoyance and asthmatic symptoms in relation to vehicle exhaust levels outside home: a cross-sectional study. Environ Health 2007, 6(I):29.

Publish with Bio Med Central and every scientist can read your work free of charge

"BioMed Central will be the most significant development for disseminating the results of biomedical research in our lifetime. "

Sir Paul Nurse, Cancer Research UK

Your research papers will be:

- available free of charge to the entire biomedical community

- peer reviewed and published immediately upon acceptance

- cited in PubMed and archived on PubMed Central

- yours - you keep the copyright

Submit your manuscript here:

http://www.biomedcentral.com/info/publishing_adv.asp
BioMedcentral 